\title{
PENANAMAN NILAI PENDIDIKAN DALAM BUDAYA MASYARAKAT GUNUNG BONGAK
}

\author{
Erlan Muliadi \\ Universitas Islam Negeri Mataram \\ Email: erlanmuliadi@uinmataram.ac.id
}

\begin{abstract}
Abstraks: Tujuan Penelitian ini adalah mendeskripsikan tentang nilai budaya lokal yang masih eksis dijadikan sebagai proses edukasi dalam melestarikan budaya lokal desa tumpak. Kedua, cara atau model yang dilakukan oleh masyarakat lokal dalam mempertahankan dan melestarikan budaya lokal desa tumpak. Metode penelitian ini merupakan metode penelitian kualitatif dan pendeketaan antropologi budaya. Dengan metode dan pendekatan yang penulis gunakan beberapa temuan masih eksis di dusun bongak desa tumpak diantaranya: Budaya Perkawinan (Midang, mereweh, Melaiq-merariq, sejati-selabar, embait wali dan nagih), Budaya Merayakan Hari Besar Islam, Budaya Lokal Acara Selametan kematian (betangi), Budaya Begarap, Budaya Persik Gubuk, Budaya larangan Menonton Televisi Pada Anak dan Budaya dalam Pribahasa Agama betakaq adat. Dari budaya-budaya yang ekssis tersebut sarat akan nilai-nilai kekeluargaan, kebersamaan persaudaraan, nilai saling menghargai, nilai menghormati, nilai tanggung jawab, nilai moral atau akhlak, nilai toleransi, nilai Acceptance (penerimaan), nilai kemandirian dan sikap ketidak tergantungan, Nonviolence (sikap tidak melakukan kekerasan). Nilai Courteos sikap empati terhadap orang lain dan ditunjukkan dengan spontan.
\end{abstract}

Kata Kunci: Nilai-nilai Pendidikan, Budaya Masyarakat

Title: Investment of Education Values In Bunak Mountain Culture

\begin{abstract}
The purpose of this study is to describe the local cultural values that still exist as a process of education in preserving the local culture of the village of tumpak. Second, the method or type accepted by the local community in maintaining and preserving the local culture of the village of tumpak. This research method is a qualitative research method and cultural anthropology approach. With the method and approach that the author uses, some findings still exist in the village of Bongak, which includes: Marriage Culture Midang, Mereweh, Melaiqmerariq, sejati-selabar, embait wali, and nagih), Culture Celebrating Islamic Holidays, Local Culture Selametan (celebrate) death event (Betangi), Begarap Culture, persik Huts Culture, Culture prohibition of Watching Television on Children and Culture in Religious Proverbs betakaq adat. From the existing cultures are full of family preferences, society affection, the importance of mutual respect, conditions of respect, values of responsibility, ethical or moral values, values of tolerance, values of acceptance, values of independence and attitude of independence, nonviolence (attitude of non-violence). Courteous values empathy towards others and is shown spontaneously.
\end{abstract}

Keywords: Educational V alues, Community Culture. 


\section{PENDAHULUAN}

Krisis nasional yang terjadi dekade ini meruntuhkan paradigma pembangunan yang dianut negeri ini dan mulai menyentuh wilayah paling mendasar yakni kebudayaan. ${ }^{1}$ Sebuah keniscayaan bangsa ini dengan karakteristiknya yang plural yang kaya akan kemajemukan terwujud dalam bentuk etnis, bahasa daerah, tradisi, adat istiadat, seni, budaya dan agama. Sebagaimana digambarkan sosiolog Amerika Hildret Geertz dalam Faisal Ismail bahwa terdapat lebih dari 300 kelompok etnis yang berbeda-beda di Indonesia masing-masing dengan identitas kebudayannya dan lebih dari 250 bahasa daerah dipakai dan hampir semua agama dunia diwakili. ${ }^{2}$

Melihat kekayaan budaya dari bangsa ini maka tentunya harus dipertahankan, dilestarikan sehingga dapat diwarisi secara turun menurun ke generasi selanjutnya. Proses pewarisan kebudayaan yang mestinya dilakukan ini selanjutnya dapat melalui proses penanaman nilai dan pembiasaan yang disebut dengan pendidikan kebudayaan, sehingga budaya majemuk yang ada dapat terjaga kelestariaannnya. Pendidikan semacam ini menjadi sebuah gerakan penyadaran bagi masyarakat untuk terus belajar sampai akhir hayat tentunya ditujukan untuk bekal hidup dalam menghadapi perubahan global yang semakin ketat dan berat. Melihat ini pendidikan mencakup setiap aspek dan proses kebudayaan dimana kesadaran akan pentingnya pendidikan untuk perubahan hidup dan bahkan melalui kebudayaan melingkupi cara berfikir, dan bertindak, keterampilan sikap cara bertindak dengan menggunakan pranata-pranata seperti lembaga sekolah yang secara sengaja diciptakan untuk tujuan tersebut serta memupuk mental yang kuat. ${ }^{3}$

Oleh karena itu pendidikan merupakan proses kebudayaan yang bisa terjadi dimana saja dan kapan saja dalam bentuk interaksi maupun internaliasi budaya diantara anggota masyarakat. Bentuk interaksi budaya yang dimaksud senada dengan tujuan pendidikan yang menuntut terjadinya perubahan-perubahan diantaranya: Pertama, tujuan individu yang saling berkaiatan dengan individu lainnya untuk mencapai perubahan yang lebih baik berdasarkan hasil interaksi. Kedua, tujuan sosial yang berkaitan dengan kehidudpan masyarakat sebagai keseluruhan, dengan tingkah laku masyarakat umumnya yang berkaitan dengan kehidupan, pertumbuhan, menambah pengalaman dan kemajuan. Ketiga, tujuan-tujuan profesional yang berkaitan dengan pendidikan dan pengajaran sebagai ilmu, seni dan sebagai suatu aktivitasaktivitas masyarakat. ${ }^{4}$ hal senada diungkapkan oleh Wiliam F.O'neil tertuang dalam ideologi pendidikan disebutkan bahwa Pertama, Sasaran Kehidupan adalah perilaku efektif dimana

\footnotetext{
${ }^{1}$ Abdul Munir Mulkhan, Nalar Spiritual Pendidikan, Solusi Problem Filosofis Pendidikan Islam, (Yogyakarta: PT. Tiara Wacana, 2002), h. 315

${ }^{2}$ Faisal Ismail, Pijar Islam Pergumulan Kultur dan Struktur, (Yogyakarta: LESFI, 2003), h. 229

3 Zubaidi, Pendidikan Berbasis Masyarakat, Upaya Menawarkan Solusi Terbadap Berbagai Problem Sosial, (Yogyakarta: Pustaka Pelajar, 2009), h. 131

${ }_{4}^{4}$ Omar Mohammad Al-Toumy, Falsafah Pendidikan Islam, (Jakarta: Bulan Bintang, 1979), h. 399
} 
prilaku efektif didasarkan pada pemikiran efektif yang melahirkan pemecahan masalah sehingga kebutuhan manusia dapat tercapai dalam kehidupannya. ${ }^{5}$

Pertama, Mempelajari tingkah laku dan mencoba untuk merumuskan definisi yang dianggap dapat memberikan penjelasan. Eisemberg dan Fabes secara sederhana memberikan pengertian sebagaia berikut "Valuntary Behavior Intended To Benefit Another, yakni tingkah laku sosial adalah tindakan menolong orang lain. ${ }^{6}$ Durkheim, Bahwa tindakan sosial tersebut tidak terlepas dari hukum-hukum solidaritas masyarakat serta keyakinan masyarakat tentang baik buruknya suatu tindakan, di setiap tindakan terdapat sanksi kaidah hukum yakni, sanksi represif dan restitutif. ${ }^{7}$ Kedua, nilai budaya, dalam setiap kelompok masyarakat pendidikan itu diselenggarakan baik secara formal melalui lembaga pendidikan, dan informal melalui berbagai bentuk komunikasi sosial. ${ }^{8}$ Etnologi atau ilmu bangsa-bangsa menurut Koentjaraningrat, 1990 yang dikutip Winny adalah ilmu yang mencoba mencapai pengertian mengenai asas-asas manusia, dengan mempelajari kebudayaan-kebudayaan dalam kehidupan manusia dari berbagai suku bangsa yang tersebar di dunia pada masa sekarang. ${ }^{9}$

Ketiga, Kajian antropologi adaptasi nilai sangat luas namun tidak terlepas dari kajian persoalan masyarakat dan yang memungkinkan institusi pendidikan merekam berbagai persoalan dalam masyarakat tersebut. Bila dikaitkan dengan berbagai unsur-unsur seperti yang diungkapkan oleh Nasution dalam Muhyi Batubara budaya tidak hanya menjadikan pendidikan sebagai objek melainkan melihat permasalahan-permasalahan budaya dalam pendidikan. ${ }^{10}$ Terbentuknya adaptasi nilai di mana masyarakat mampu menyesuaikan diri dan harmonisai diri dilingkungan tempat tinggalnya dan bahkan mampu beradaptasi dari pengaruh budaya luar, sehingga proses penyesuaian tersebut membentuk tiga model lingkungan di mana manusia hidup. 1). Lingkungan material 2). Lingkungan sosial, 3). Lingkungan simbolik. ${ }^{11}$

\footnotetext{
${ }^{5}$ Wiliam F. O'neil, Ideologi-Ideologi Pendidikan, (yogyakarta: Pustaka Pelajar, 2008), h. 283-284

${ }^{6}$ Desmita, Psikologi Perkembangan Peserta Didik, Panduan Bagi Orang Tua dan Guru dalam Memahami Psikologi Anak, Sudia SD, SMP dan SMA (Bandung: PT. Rosda Karya, 2012), h. 235

${ }^{7}$ Represif dapat dilihat pada masyarakat yang didasarkan pada solidaritas mekanis. Dan sanksi restitutif terdapat apada masyarakat atas dasar solidaritas organis. Lihat Soerjono Soekanto, Sosiologi Sebuah Pengantar, (Jakarta: PT. Raja Grafindo Persada, 2007), h.9

8 Winny Puspasari Thamrin, dkk. Antropologi, Opcit., h. 10.

${ }_{9}$ Christoph Stückelberger, Philosophy, Ethics and Local Wisdom in the Moral Construction of the Nation. Terjemahan Siti Syamsiyatun dan Nihayatul Wafiroh, Filsafat, Etika, dan Kearifan Lokal untuk Konstruksi Moral Kebangsaan, (Geneva: Globethics.net, 2013), h. 208

10 H. Muhyi Batubara, Sosiologi Pendidikan, (Jakarta: Ciputat Press, 2004), h. 37-47

11 Dimaksud dengan material disini bukanlah sebuah ekosistem melainkan lingkungan buatan manusia, seperti rumah, jembatan, sawah dan peralatan-peralatan ciptaan. Sedangkan lingkungan sosial adalah lingkungasn organisasi sosial, stratifikasi, sosialisasi, gaya hidup. Sedangkan lingkungan simbolik segala sesatu yang memiliki makna dan komuniakasi (bahasa, mite, nyanyian, seni, upacara, tingkah laku, benda dan konsepkonsep. Lihat Kuntowijoyo, Budaya dan Masyarakat Edisi Paripurna, (Yogyakarta: Tiara Wacana, 2006), h. 89
} 
Keempat, Internalisasi, tujuan umum pendidikan adalah menanamkan nilai-nilai, normanorma sehingga membentuk manusia terdidik dan sadar akan realitas dunianya, praktik manusia merupakan aktivitas manusia yang tidak terlepas dari proses belajar manusia sebagai anggota masyarakat yang menentukan perkembangan kebudayaan umat manusia, sehingga kecenderungan menggunakan istilah kebudayaan sebagai payung besar dari berbagai macam kegiatan manusia sebagai homo sapiens. ${ }^{12}$ Sebagaimana disebutkan Alfred Schutz bahwa manusia mempunyai conciusness atau kesadaran tentang sesuatu yang merefleksikan dirinya dalam bentuk fenomena atau gejala sosial budaya sebagaimana adanya. ${ }^{13}$

Sehingga pendidikan dimaknakan sebagai leaarning society yakni setiap pengalaman manusia tercipta dengan lingkungan sosialnya. Dengan demikian Budaya memiliki peran penting dalam mengambil sebuah konep dan nilai dalam pendidikan, di mana budaya lokal sebagai ciri dan karakter masyarakat dan sekaligus sebagai identitas suatu bangsa, kemajuan pendidikan dapat diukur dari majunya dan terjaganya sebuah kebudayaan lokal yang mampu menkonstruk perubahan lebih luas dan universal.

Terkait dengan hal tersebut maka nilai-nilai budaya lokal yang ada di Dusun Bongak menjadi realitas terbentuknya nilai budaya nasional yang kokoh, sehingga pendidikan sebagai penanaman nilai budaya tetap eksis berperan di tengah masyarakat lokal dan nasional. Berangkat dari hal terbut di atas pendidikan menjadi barometer berkembang dan majunya sebuah desa bahkan negara secara luas. Namun pemahaman masyarakat terhadap pendidikan hanya di bangku sekolah dan perguruan tinggi saja, bahkan banyak di antara masyarakat kita juga mengabaikan pendidikan anaknya disebabkan banyak hal, di antaranya sebagian masyarakat beranggapan bahwa pendidikan tidak bisa mengahsilkan materi yang cukup bahkan sebaliknya menghabis-habiskan uang. Pola pikir seperti inilah kemudian menyebabkan rendahnya sumber daya manusia yang berdampak pada menghambat cita-cita anak bahkan juga menyebabkan terjadinya berbagai problem di tengah masyarakat, seperti kenakalan remaja, pertikaian antar kampung/desa dll. ${ }^{14}$ Dengan berbagai proplematika di atas, peneliti akan mengkaji tentang (1)bagaimana nilai budaya lokal yang masih eksis dijadikan sebagai proses edukasi dalam melestarikan budaya lokal desa tumpak, (2) bagaimana cara atau model yang dilakukan oleh masyarakat lokal dalam mempertahankan dan melestarikan budaya lokal desa tumpak.

12 Adapun konsep universal yang dimaksudkan adalah unsur-unsur kebudayaan universal diantaranya sistem religi dan upacara keagamaan, sistem organisasi kemasyarakatan, sistem pengetahuan, bahasa, kesenian, sistem mata pencaharian dan terhir sistem teknologi. Syamsul Arifin, Studi Agama, Perspektif Sosiologi dan Isu-Isu Kontemporer, (Malang: UMM Pres, 2009). h. 101-104

${ }^{13}$ Khadziq, Islam dan Budaya Lokal, Belajar Memahami Realitas Agama dalam Masyarakat, (Yogyakarta: Teras Press, 2009), h. 137-139

${ }^{14}$ Ibid., h. 227 


\section{METODE PENELITIAN}

Penelitian ini merupakan penelitian kualitatif yang memiliki tujuan utama untuk memahami fenomena atau gejala sosial dengan lebih menitik beratkan pada gambaran yang lengkap tentang fenomena yang dikaji daripada memerincinya menjadi variabel-variabel yang saling terkait. Harapannya ialah diperoleh pemahaman yang mendalam tentang fenomena untuk selanjutnya dihasilkan sebuah teori. Dalam penelitian kualitiatif kehadiran peneliti di lokasi penelitian adalah sebagai instrumen kunci dalam upaya menemukan data melalui pengamatan atau observasi secara langsung atau observasi partisipasi dan observasi nonpartisipasi

Supaya lebih terfokus, penelitian ini juga menggunakan pendekatan antropologi pendidikan. Penelitian ini mengguanakan bagian dari kajian antropologi yang lebih mendekati yaitu indigeneus learning yakni sebuah proses pembelajaran yang dilakukan secara turun temurun yang terjadi dalam suatu komunitas, suku atau etnik tertentu yang didasarkan pada kebiasaan sistem budaya, ekonomi, dan spiritual yang menjadi ciri khas lokalitas. Mempelajari tingkah laku dan mencoba untuk merumuskan definisi yang dianggap dapat memberikan penjelasan. Eisemberg dan Fabes secara sederhana memberikan pengertian sebagaia berikut "Valuntary Behavior Intended To Benefit Another, yakni tingkah laku sosial adalah tindakan menolong orang lain. ${ }^{15}$

\section{TEMUAN DAN PEMBAHASAN}

Nilai Budaya Lokal Yang Masih Eksis Dijadikan Sebagai Proses Edukasi Dalam Melestarikan Budaya Lokal Desa Tumpak

Sikap dan perilaku mereka mencerminkan masyarakat terdidik yang masih jauh dari pengaruh-pengaruh negatif perkotaan atau masyarakat modern pada umunya, nilai-nilai sosial dalam masyarakat tersebut dapat disimpulkan ke dalam beberapa sub nilai diantaranya: Pertama, Love (kasih sayang) yang terdiri atas pengabdian, tolong menolong, kekeluargaan, kesetiaan, dan kepedulian. Kedua, responsibility (tanggung Jawab) yang terdiri atas nilai rasa memiliki, disiplin dan empati. Ketiga, life harmony keserasian hidup yang terdiri atas nilai keadilan, toleransi, kerjasamsa, dan demokrasi. Dengan melihat sub nilai ini tampak jelas bahwa nilai-nilai sosial yang ada dimasyarakat sangat penting dan tercermin dalam pribadi individu. ${ }^{16}$ terkait dengan hal tersebut beberapa nilai-nilai budaya lokal yang bisa peneliti ambil sebagai tradisi dan kebiasaan masyarakat sarat nilai pendidikan diantaranya:

15 Desmita, Psikologi Perkembangan Peserta Didik, Panduan Bagi Orang Tua dan Guru dalam Memahami Psikologi Anak, Sudia SD, SMP dan SMA (Bandung: PT. Rosda Karya, 2012), h. 235

16 Zubaedi, Pendidikan Berbasis Masyarakat Upaya Menawarkan Solusi Terhadap Berbagai Problem Sosial. (Yogyakarta: Pustaka Pelajar, Cetakan V, 2009), h. 13-14 
1. Internalisasi Nilai-Nilai Pendidikan dalam Budaya Perkawinan

Perkawinan disemua tempat dan oleh siapapun akan mengalami diamping itu sebagai sunnah dalam Islam juga kebutuhan manusia untuk berkembang menambakn koloni seperti makhluk hidup pada umumnya. Begitu juga dengan tradisi perkawinan yang terjadi di berbagai daerah memiliki cirikhasnya masih-masing, dusun bongak salah satu dusun yang memiliki tradisi kebudayaan yang masih tetap terjaga sampai saat ini dan menjalankan tradisi tersebut dengan diimbangi dengan pemahaman masyarakatnya, sebagaimana yang dipaparkan pada bagian terdahulu bahwa perkawinan di dusun bongak dimulai dari beberapa tahapan diantaranya: proses midang atau dalam Islam dinamakan ta'arruf proses mengenal pasangan baik lingkungan dia tinggal atau lebih dekat dengan keluarga calon istri atau suaminya kelak.

Pada prinsipnya bagaimanapun bentuk dan sistem pelaksanaan dalam ritual perkawinan tidak terlepas dari satu tujuan yang ingin dicapai oleh semua manusia yaitu kebahagiaan, kenyamaan, kelanggengan dunia dan akhirat (sakinah, mawaddah dan warahmmah), keinginan tersebut merupakan tujuan perkawinan, sejalan dengan hal demikian masyarakat dusun bongak tidak melepas diri dari ketentuan agama dan adat sehingga tujuan dan nilai-nilai dalam perkawinan dapat tercapai.

Proses midang-pun tidak terlepas dari nilai-nilai etika dan moral budaya, misalkan dalam aturan adat sasak dan dusun bongak midang hanya boleh dilakukan pada malam hari dan harus pulang dari perempuan yang dipidang sudah berpamitan pada jam 10 malam tidak boleh lebih, sebab akan dikarenakan sanksi minimal berupa tidak dibolehkan datang lagi ke rumah atau desa tempat perempuan tersebut. Tujuan dijadwalkannya waktu midang tersebut sebagai bentuk penghormatan terhadap si perempuan dan keluarganya karena pada malam hari semua keluarga kumpul di rumah setelah seharian bekerja, kemudian diwajibkan pulang di jam tertentu untuk penghormatan pula terhadap orang lain bahwa untuk beristirahat dengan cukup karena besok akan bekerja kembali. Sebagaimana yang diungkapkan fathul mu'in bahwa setiap manusia membutuhkan penghormatan atau dihormati, penghormatan itu bukanlah sesuatu hal yang diminta, melainkan diberikan jadi keluarga perempuan memang tidak mengharapkan untuk dihormati penuh dengan rekayasa namun kita sadar dan mulai menata sikap dan posisi kita agar orang lain merasa sikap itu memang benar tidak dibuat-buat. ${ }^{17}$

Nilai yang dapat diambil sebagai bahan edukasi yang lain dalam perkawinan sebelum samapi ke jenjang pelaminan adalah mereweh, Nari, Melaiq merariq dan sejati selabar, tahapan-tahapan ini sarat akan nilai pendidikan dalam kehidupan berbudaya dan bermasyarakat, dalam mereweh dan melaiq merariq misalkan pemberian ikhlas dan

${ }^{17}$ Fathul Mu’in, Pendidikan Karakter..., h. 213 
keberanian dari seorang laki-laki kepada calon pasangan hidupnya itu sebagai bentuk nilai tanggung jawab (value responsibility) bahwa dalam hidup itu harus memiliki arah dan tujuan dan berani mengambil keputusan seberat apapun sebagai bentuk proses pendewasaan dalam mengaruhi bahtera kehidupan. Jika Responsibility sudah tertanam dalam diri setiap individu maka menjadikan manusia mandiri, tegar dalam menghadapi maslah dan tidak mudah putus asa.

Berbeda dengan tradisi lokal embait wali, tradisi ini memiliki nilai-nilai edukasi di mana rasa saling menghargai dan tanggungn jawab tercermin dari tata cara merupakan bagaimana menghormati orang lain sehingga dengan penghormatan yang kita berikan orang lain merasa nyaman ketika masuk dilingkungan kita atau keluarga, sehingga harus diselesaikan dengan cara kekeluargaan atau adat, bahkan orang yang embait wali atau jemput wali harus orang yang paham bahasa, tata cara adat, dan pandai berkomunikasi secara adat pula. Seperti yang diungkapkan bapak harun bahwa embait wali ini harus keluarga yang sudah dituakan dan didampingi oleh pemangku adat serta aparatur dusun (kadus) sehingga tidak dikatakan pelecehan secara adat nantinya.

Nagih dalam tradisi perkawinan masyarakat bongak sudah mengakar kuat dan menjadi salah satu ukuran sah dan tidaknya suatu perkawinan jika mengikuti secara teratur aturan adat yang ada, selama aturan adat itu tidak bertentangan dengan agama dan merugikan diri sendiri serta orang lain, di berbagai literatur yang ada memang persoalan adat perkawinan di sasak lombok sudah bukan rahasia lagi, berbagai bentuk dan tujuan penelitian sudah dilakukan, namun jarang yang melihat nilai-nilai yang ada di dalam tradisi perkawinan tersebut terutama persoalan tradisi nagih ini. Kaitannya dengan hal tersebut pada pelaksanaan adat nagih dalam perkawinan masyarakat bongak terdapat pandangan yang berbeda-beda ditengah-tengah mereka yang mentradisikannya (masyarakat bongak) disebabkan perbedaan paradigma berpikir, namun secara umum disini peneliti paparkan ada tiga pandangan masyarakat bongak mengenai tradisi nagih, diantaranya adalah: Pertama, kelompok kodek atau minotitas pandangan yang tidak setuju dengan tradisi nagih kelompok ini biasanya mereka yang sedang mengalami tagihan atau sudah mengalaminya dan jumlahnya sangat sedikit atau bisa dikatakan sebagai kelompok minoritas.

Ada berbagai alasan mereka menolak tradisi ini dianataranaya adalah bahwa tradisi adat tersebut tidak ada ketentuan di dalam hadis ataupun al-Quran atau bertentangan dengan syariat agama, kemudian anak perempuan tidak untuk diperjual belikan melainkan diberikan hak dan tanggung jawab yang sama seperti anak laki-laki, selanjutnya alasan terakhir dari kelompok minoritas ini adalah tradisi nagih menyebabkan rusaknya kerukunan antar persaudaraan karena menimbulkan dendam yang berlarut-larut. 
Kedua, kelompok belek atau mayoritas, pandangan terhadap tradisi nagih ini mereka setuju disebabkan tradisi ini sudah menjadi warisan leluhur yang wajib dilestarikan oleh generasi kegenerasi, selain itu adat nagib ini memberikan tanggung jawab kepada suami atau orang tua yang bersangkutan dan dapat menjalin hubungan persaudaraan dan tali silaturrahim antar keluarga, adapun pandangan minoritas tadi di atas disanggah bahwa adat nagih dapat menimbulkan dendam itu dibantah oleh kelompok mayoritas, diungkapkan oleh bapak harun selaku kelompok mayoritas di dusun bongak dengan tradisi nagih ini memang keluarga yang tertagih merasa terbebani namun masalah cara dan bagaimana menagih harus sesuai dengan adat dan budaya yang sudah ada sehingga dapat terhindar dari rasa dendam ataupun benci. Jika dengan cara yang sopan, baik, halus lemah lembut maka tidak ada satupun orang yang akan merasa tersinggung ataupun marah.

Nilai-ilai yang dapat diambil dari tradisi nagih ini berupa bagaimana cara mempertahankan status sosial dan harga diri keluarga secara utuh dan turun temurun, rasa tanggung jawab yang tinggi harus terbentuk sedemikian rupa, apalagi jika sudah memiliki seorang anak laki-laki maka sebagai orang tua harus siap dan bekerja keras untuk membahagiakan anak-anak mereka terutama ketika membutuhkan perlindungan orang tuanya, di sana seorang anak benar-benar memanfaatkan orangtuanya dan sebagai bentuk pembuktian kepada sang anak dia benar-benar diberikan perhatian sampai ia mandiri atau menikah. Hal senada sejalan dengan teori yang diungkapkan oleh individu maupun masyarakat memiliki tujuan yang sama, yakni sebagai makhluk sosial kita dapat mengambil manfaat dan senantiasa bekerja sama dengan orang lain tapi itu bukan pamrih. Lebih lanjut Jhering mengungkapkan bahwa tidak seorangpun ketika berbuat sesuatu untuk orang lain tanpa pada saat yang bersamaan ingin melakukan sesuatu bagi dirinya sendiri (simbolis mutualis) sama-sama saling memberi keuntungan. ${ }^{18}$

2. Internalisasi Nilai-Nilai Pendidikan dalam Budaya Perayaan Hari Besar Islam

Dusun bongak merupakan masyarakat yang memegang teguh kepercayaan dan keyakinan agamanya, sejalan dengan ajaran Islam masyarakat bongak tidak bisa terlepas dari perayaan hari-hari besar Islam seperti merayakan maulid nabi, isra' mi’raj, malam nuzulul qur'an dan hari raya idul fitri serta adha, semua hari-hari besar Islam tersebut dirangkaikan dengan budaya setempat tentunya tidak terlepas dari ajaran Islam, dalam meningkatkan keimanan kepada Allah masyarakat bongak di setiap hari besar melakukan zikir bersama dan mendatangkan tokoh-tokoh agama untuk mengisi hari-hari besar tersebut untuk melakukan tausiah dan pengajian di masjid.

Adapun tujuan perayaan tersebut tidak lain untuk memperkuat dan mendekatkan diri pada ajaran tahuid, karena dalam Islam kita mengenal adanya konsep tauhid, suatu

${ }^{18}$ Bernard L. Tanya dkk. Teori Hukum strategi lintas ruang dan generasi. (Surabaya: CV Kita, 2007), h. 124 
konsep sentral yang berisi ajaran bahwa Tuhan adalah pusat dari segala sesuatu manusia harus mengabdikan diri sepenuhnya kepadannya, koosep tahuid ini mengandung implikasi doktrinal bahwa tujuan hidup manusia adalah untuk menyembah dan menyadari posisinya sebagai mahluk yang diciptakan. Dengan kata lain ajaran tahuid memusatkan pada yang satu yakni sang kholik yakni konsep teosentris bahwa nilai yang dibangun selalu berkaitan dengan amal yaitu perbuatan dan tindakan manusia, dengan demikian iman harus diaktualisasikan menjadi amal kemudian menjelma menjadi aksi kemanusiaan dengan tujuan untuk terwujudnya kesejahteraan sosial, sehingga dalam perayaan tersebut tercermin kebersamaan dalam membangun kelompok masyarakat religius dan humanis maksudnya adalah manusia terpusat kepada tuhan namun tujuannya untuk kepentingan manusia sendiri atau dengan kata lain bumanisme-teosentris ${ }^{19}$. Dengan demikian dalam ritual perayaan hari besar Islam yang dilakukan oleh masyarakat bongak selain membentuk kesalehan individu juga sekaligus membetuk kesalehan sosial yang peduli terhadap sesama.

3. Internalisasi Nilai-Nilai Pendidikan Melalui Budaya Lokal Acara Selametan Kematian

Penanaman nilai pada hari selamatena kematian di dusun bongak sarat akan nilainilai edukasi, bahwa setelah dilahirkan akan mengalami kematian sehingga setiap yang mengalami mati harus diurus dengan sebaik-baiknya sebagai bentuk tali persaudaraan yang satu dengan yang lainnya masih terjaga dan terjalin baik. Nilai-nilai persaudaraan dan kesadaran bahwa manusia membutuhkan manusia yang lain sangat terasa ketika kematian ini terjadi. Secara adat ritual kematian masyarakat bongak tidak jauh beda dengan masyarakat lombok pada umumnya namun ada ritual-ritual tertentu yang menjadi nilai lebih di masyarakat bongak, seperti yang disampaikan oleh bapak kadus bongak 2 Bapak Arip, SPd.I setelah melakukan pemakaman masyarakat bongak pada malam hari sampai hari kesembilan melakukan zikir dan tangi. Zikiran dilakukan oleh semua warga yang ada di dusun bongak setelah sholat magrib sampai selesai kira-kira satu jam kemudian, jamaah zikiran dihidangkan makanan ringan kopi bahkan hidangan makan malam. Setelah melakukan zikiran masyarakat bongak secara bergantian di rumah keluarga al-marhum melakukan ritual tangi. ritual tangi ini hanya sebagian masyarakat bongak yang meyakininya dan praktiknya juga kadang dilakukan dan kadang juga tidak, disebabkan tradisi ini menurut sebagian masyarakat sudah cukup dengan zikiran saja untuk mendoakan yang meninggal.

Patuk: adalah pemberian seperangkat pakaian sholat berupa kain sarung dan mukenah sebagai ucapan syukur dan terima kasih karena telah mengurus keluarga mereka yang meninggal baik mulai dari memandikan mengantarkan al-marhum/almarhumah

${ }^{19}$ Kuntowijoyo, Paradigma Islam Intrefetasi Untuk. Aksi. (Bandung: Mizan Media Utama, Cetakan I 2008), h. 281-283 
sampai ke liang kubur adapun pemberian seperangkat alat sholat itu diberikan kepada pemangku adat, tokoh agama, tokoh masyarakat atau kadus yang menjadi aparatur dusun. Tradisi ini sudah terjadi sejak lama dan masyarakat setempat terus melestarikan budaya itu di setiap ada salah satu masyarakat mereka yang meninggal. Tidak ada sanksi berupa denda jika tidak melaksanakan patuk bagi keluarga yang ditinggalkan namun tradisi ini sebagai bentuk syukur bahwa masyarakat sekitar sukarela membantu. Budaya patuk ini juga disamping memberikan keringanan terhadap keluarga yang berduka disisi lain masyarakat atau tokoh agama merasa dihargai dan dihormati walaupun pemberian itu hanya berupa pakaian, namun masyarakat dusun bongak tidak melihat nilai materinya melainkan semangat kerja sama dan saling menghargai, bahkan bukan hanya tokoh agama dan adat yang diberikan, keluarga yang memandikan, mengkafani dan yang memilkul jenazah sampai kepemakaman pun diberikan hal yang sama berupa kain tersebut.

Jadi jika dilihat dari bentuk dan struktur masyarakat yang demikian maka dapat dikelompokkan ke dalam kategoti budaya tradisonal di mana masih kentalnya akan nilainilai persaudaraan atau swadaya masyarakat, masyarakat swadaya sendiri dalam bekerja sama di tengah-tengah masyarakat tanpa mengharapkan pamrih dan biasanya masyarakat swadaya ini masih dapat ditemukan di daerah-daerah terpencil, dengan sistem swadaya tersebut masyarakat mampu mandiri tanpa bergantung terhadap dunia luar atau desa lain yang lebih maju. ${ }^{20}$ Seperti yang diungkapkan tokoh agama Bapak Harun bahwa pemberian itu semata-mata untuk menunjukkan kepedulian dan kasih sayangnya terhadap yang meninggal dunia, karena keluarga yang masih hidup mampu memberikan dan menjalankan adat dan agama untuk almarhum.

KH. Husein Muhammad mengatakan bahwa masyarakat tradisional sebagai literatur keislaman yang bercorak dan berpola pemikiran konserfatif produktif. Disamping praktik-praktik yang bercorak fiqih yang telah lama dipegang, praktik sufi dan tarekat di sisi lain telah membentuk kepribadian masyarakat muslim yang cenderung memprioritaskan kesalehan individu dari pada kesalehan sosial. Dalam pengertian konteks epistemologi ilmu, nalar dan dimensi moral lebih tinggi dari pada kepekaan terhadap persoalan masyarakat. ${ }^{21}$ Dari kecenderungan tersebut masyarakat pedesaan mampu membendung arus globalisasi modern yang semakin hari dapat menjerumuskan mereka. Berangkat dari hal tersebut Eisemberg dan Fabes secara sederhana memberikan pengertian sebagaia berikut "Valuntary Behavior Intended To Benefit Another, yakni tingkah

\footnotetext{
${ }^{20}$ Kuntowijoyo, Paradigma Islam Intrefetasi Untuk. Aksi. (Bandung: Mizan Media Utama, Cetakan I 2008), h

${ }^{21}$ H. Afandi Mochtar, Kitab Kuning Dan Tradisi Akademik Pesantren, (Jakarta: Pustaka Isfahan, 2010), h. 17
} 
laku sosial adalah tindakan menolong orang lain. ${ }^{22}$ Durkheim, Bahwa tindakan sosial tersebut tidak terlepas dari hukum-hukum solidaritas masyarakat serta keyakinan masyarakat tentang baik buruknya suatu tindakan, disetiap tindakan terdapat sanksi kaidah hukum, sanksi represif dan restitutif.

4. Internalisasi Nilai-Nilai Pendidikan Melalui Budaya Begarap

Budaya begarap sebagai bentuk peradilan lokal, ketika ada salah satu warga yang merasa dirugikan atau kehilangan maka dilakukanlah begarap. Terdapat pesan moral yang terkandung di dalamnya, dengan sistem begarap ini masyarakat tidak berani melakukan hal-hal buruk berbuat kesalahan bahkan melakukan pencurian. Kemudian dengan begarap ini mendidik masyarakat supaya tidak main hakim sendiri atau berlaku sewenang-wenang terhadap orang lain yang dicurigai, namun setiap permasalahan yang ada harus diselesaikan bersama dengan cara adat. Hukum yang ditimbulkan sebab begarap membuat efek jera terhadap pelaku atau orang yang melakukan pencurian dan kesalahan terhadap orang lain.

Dengan demikian sistem begarap dapat memberikan pesan moral dalam dunia pendidikan sebagaimana diungkapkan Munir Mulkhan bahwa pendidikan seharusnya dapat dijadikan sebagai wahana pembelajaran dalam menyelesaikan problem kehidupan yang sedang dan akan dihadapi, pendidikan bukan hanya peniruan dan paket gaya hidup. ${ }^{23}$ Lebih lanjut apa yang diungkapkan zubaedi dalam tulisannya bahwa untuk membangun karakter masnusia diperlukan conscience (kesadaran), self-esteem (kepercayaan diri), empathy (merassakan penderitaan orang lain), loving the good (cinta kepada kebaikan), self control (kontrol diri), bumility (kerendahan hari). Dari penanaman moral itu melahirkan perbuatan-perbuatan moral yang dapat mengontrol diri dan lingkungan dimana ia tinggal. ${ }^{24}$

Begitu halnya dengan persik gubuk, salah satu media adat yang digunakan adalah dengan begarap ini. Jadi, masyarakat lebih mementingkan problem itu diselesaikan di dalam komunitas mereka terlebih dahulu daripada masalah itu diserahkan secra hukum positif yang berlaku dinegara Indonesia, sehingga dalam adat begarap ini terjadi perbedaan dengan masyarakat yang satu dengan yang lainnya dengan alasan-alasan sebagaimana disebutkan di atas, ada yang beranggapan bahwa begarap ini lebih banyak mudaratnya dari pada manfaatnya, di satu sisi masyarakat yang setuju ini adalah warisan nenek moyang harus di lanjutkan dan di jaga sehingga kita sebagai generasi penerus menghormati apa yang sudah menjadi kepercayaan orang tua kita. Jadi menurut analisa peneliti tradisi

${ }^{22}$ Desmita, Psikologi Perkembangan Peserta Didik, Panduan Bagi Orang Tua dan Guru dalam Memahami Psikologi Anak, Sudia SD, SMP dan SMA (Bandung: PT. Rosda Karya, 2012), h. 235

${ }^{23}$ Abdul Munir Mulkhan, Nalar Spiritual Pendidikan, Solusi Problem Pilosofis Pendidikan Islam. (Yogyakarta: PT. Tiara Wacana, cetakan I, 2002), h. 163

${ }^{24}$ Zubaedi, Pendidikan Berbasis Masyarakat Opcit., (Yogyakarta: Pustaka Pelajar, Cetakan V, 2009), hal. 7-8 
begarap ini merupakan warisan budaya pendahulu masyarakat bongak yang sistem dan mekanismenya sudah terkikis dan kehilangan ruhnya sehingga tradisi ini menjadi pertentangan dan perdebatan di tengah masyarakat.

5. Internalisasi Nilai-Nilai Pendidikan Melalui Budaya Melarang Menonton Televisi Pada Saat Anak Belajar Mengaji

Lahirnya larangan menonton televisi ketika anak-anak akan belajar mengaji disebabkan semangat orang tua untuk mendidik dan menganjurkan anak mereka belajar mengaji sangat minim dan bahkan tidak ada, sehingga tokoh adat dan tokoh agama dan masyarakat bermusyawarah membentuk aturan supaya para orang tua takut dan mau menyuruh anak mereka belajar.

Sebagaimana kita ketahui bahwa Tanggung jawab menjadi orang tua memberikan pendidikan sebaik-baiknya pada anak sudah barang tentu harus dipenuhi, pemenuhan itu dilakukan sesuai dengan kondisi lingkungan dimana anak itu tinggal. Namun peran orang tua tidak bisa dihilangkan dan dianggap remeh sehingga pendidikan anak sejak dini perlu diperhatikan. Lahirnya aturan larangan menonton televisi inilah salah satu cara yang tepat melihat kondisi masyarakat yang masih awam akan dunia pendidikan, sebagian besar orang tua mereka hanya tahu jika sudah bisa makan tiga kali sehari sudah cukup tidak perlu lagi berbuat apa dan itu apalagi mendidik anak mereka.

Lahirnya aturan tersebut tidak terlepas dari tujuan hidup yang lebih baik yakni sebagai wadah pembentukan penanaman moral sebagaimana diungkapkan Zubaedi setiap individu harus tertanam kesadaran moral (moral awerenes), menggunakan sudut pandang moral (prespectif taking), alasan moral (moral reasoning), mengambil keputusan moral (decisin making) dan pengetahuan diri (self knowledge). ${ }^{25}$

Kebanyakan orang tua mereka mencari rizki keluar negeri atau menjadi TKI ke Malaysia, maka sangat tepat diterapkannya aturan atau awiq-awiq ini didusun bongak. Sehingga pendidikan anak bukan hanya tanggung jawab orang tua mereka namun menjadi tanggung jawab bersama sebagai bagian dari masyarakat bongak.

6. Internalisasi Nilai-Nilai Pendidikan melalui Peribahasa Agama Betakaq Adat

Peribahasa dalam susku sasak sangat banyak sekali namun peneliti menemukan satu peribahasa berdasarkan wawancara dengan tokoh agama masyarakat bongak Bapak Harun yaitu agama betakaq adat. Berangkat dari hal tersebut bahasa merupakan alat komunikasi antara manusia atau sesama makhluk dan sang pencipta, dengan bahasa dapat menunjukkan kepribadian seseorang, sehingga bahasa yang baik menjadikan orang berlaku baik dan sebaliknya bahasa yang tidak baik menjadikan perilaku yang tidak baik pula. Dalam Islam mengajarkan sebagai salah satu contoh memberikan nama terhadap

\footnotetext{
${ }^{25}$ Zubaedi, Pendidikan Masyarakat..., h. 7
} 
anak harus memberikan nama yang baik dan di dalamnya sekaligus doa ketika menyebut anak tersebut. Semakin dalam makna bahasa tersebut maka akan memiliki makna yang dalam pula dalam kehidupan.

Peribahasa agama betakaq adat, memberikan gambaran bahwa manusia lahir dan hidup bersama dengan orang lain harus memahami dimana dan apa yang dikerjakan itu tidak boleh keluar dari ketentuan ajaran dan kepercayaan agama. Agama mengajarkan bagaimana berperilaku, beribadah, dan bermuamalah kemudian mengenai cara melaksanakan kewajiban-kewajiban dalam beragama tersebut manusia diberikan kebebasan sesuai dengan syaraiat yang ada seperti cara melakukan sholat, zakat puasa dan ajaran-ajaran agama lainnya.

\section{Cara Atau Model Yang Dilakukan Oleh Masyarakat Lokal Dalam Mempertahankan Dan Melestarikan Budaya Lokal Desa Tumpak}

Masyarakat dusun bongak merupakan masyarakat yang mandiri walaupun berada di lereng gunung bongak, mereka tetap eksis menjalankan kehidupan mereka sehari-hari tanpa ada problem yang begitu berat. Terlihat masyarakatnya hidup damai, tenteram, dan bersahaja, tegur sapa antar sesama serta kentalnya sistem kekeluargaan membuat masyarakat bongak semakin memperkuat karakteristik mereka. Tidak hanya dengan model simbolik kognitif dalam melestarikan nilai-nilai budaya sasak lombok, masyarakat dusun bongak menggunakan model aksi kultural yang dirangkaikan dengan duduk bersama membicarakan hubungan dan perkembangan dusun mereka. Walaupun hal ini dilakukan setahun sekali namun budaya musyawarah tersebut membuat rasa kekeluargaan mereka samakin sarat akan nilai harmonis. Ketika duduk bersama dilakukan setahun sekali mereka membahasa berbagai macam hal diantaranya; sistem tradisi yang mereka bangun dan mereview kembali apakah dengan tradisi yang sudah ada memberikan sumbangan positif bagi masyarakat atau memberikan dampak negatif semata.

Agama dan budaya manusia tidak bisa dipisahkan atau dihilangkan salah satunya, sehingga jika dihilangkan salah satunya maka tatanan kehidupan masyarakat akan terasa pincang dan semeraut walaupun dalam agama menuntut harus berlandaskan ajarannya. Walaupun demikian penjelmaan agama tersebut sudah menyatu dalam tradisi budaya manusia, begitu pula dengan masyarakat yang ada di pulau lombok khususnya masyarakat dusun bongak tradisi dan kebudayaan mereka tidak terlepas dari garis-garis besar agama sehingga tradisi mereka tidak dikatakan sebagai tradisi yang jauh dari nilai-nilai syariah. Agama dijadikan sebagai acuan perilaku dan budaya dijadikan sebagai media untuk menjalankan perilaku tersebut sehingga menjadikan budaya masyarakat dusun bongak tetap terjaga Sebagaimana yang sudah. 
Menjaga tradisi nenek moyang selain dengan sistem musyawarah masyarakat bongak juga dalam kesehariannya terlihat memberikan nasihat-nasihat kepada anak-anak mereka, misalkan ketika mereka duduk-nongkrong di berugak mereka menyempatkan diri menceritakan kisah leluhur mereka bagaimana orang-orang dahulu menyelesaikan masalah, bagaimana mereka bekerja antar sesama warga. Budaya memberikan nasehat tersebut sampai saat ini masih tetap terjaga baik walaupun itu tidak terjadwal rapi, namun budaya itu terus berjalan eksis sampai sekarang sehingga tradisi yang sudah dibangun dana berjalan lama oleh nenek moyang mereka masih tetap berlaku di tengah masyarakat. Dalam hubungan interaksi antara anak dan orang tua, sesama anggota masyarakat serta sesama masyarakat lainnya senantiasa menerima berbagai pembelajaran nilai dan norma dan bahkan menyerap ilmu pengetahuan dari lingkungan mereka tinggal. Oleh karena itu sistem musyawarah duduk bersama menjadi tradisi tahunan adalah bentuk pewarisan dan pelestarian nilai-nilai budaya.

Misalkan dalam tradisi-tradisi perayaaan hari besar Islam dilaksanakan, biasanya perayaan hari besar Islam ini dilaksanakan di satu tempat atau masjid saja. Para orang tua mereka semabari duduk dengan anak-anaknya, mereka menceritakan bahwa tradisi perayaan seperti ini sudah dari sejak dulu ketika mereka masih muda nenek, kakek mereka masih hidup, mereka mengucap syukur bahwa kebiasaan orang tua mereka dulu masih tetap terjaga dan diteruskan oleh anak-anak mereka menjadi kebanggaan tersendiri sehingga mereka tanpa sadar sudah memberikan penanaman dan pemahaman nilai-nilai pendidikan berupa penghormatan dan tanggung jawab sebagai manusia sosial dan berbudaya. Selain dengan sistem musyawarah di atas salah satu cara masyarakat bongak melestarikan budaya adalah dengan terus menjalankan segala bentuk interaksi yang mereka lakukan baik di antara mereka maupun interaksi dengan masyarakat luar, jika interaski itu bersinggungan dengan masyarakat bongak maka akan dilakukan sesuai dengan adat yang sudah ada, misalakan dalam upacara perkawinan, selametan dan adat-dat yang lainnya sebagaimana yang sudah disebutkan sebelumnya.

\section{SIMPULAN}

Dapat disimpulkan bahwa internalisasi nilai budaya lokal masyarakat bongak adalah budaya-budaya yang ekssis tersebut sarat akan nilai-nilai kekeluargaan, kebersamaan persaudaraan, nilai saling menghargai, nilai menghormati, nilai tanggung jawab, nilai moral atau akhlak, nilai toleransi, nilai Acceptance (penerimaan), nilai kemandirian dan sikap ketidak tergantungan, Nonviolence (sikap tidak melakukan kekerasan). Nilai Courteos sikap empati terhadap orang lain dan ditunjukkan dengan spontan. Nilai Polite sikap sopan menunjukkan sebagai rasa hormat bukan takut ataupun sungkan. Nilai Concerned memberikan perhatian terhadap orang lain. dan nilai religius. 
Adapun model dan cara yang di gunakan untuk melestarikan adat dan kebudayaan tersebut disusun bongak memang tidak melakukan acara khusus melainkan dengan menjalankan tradisi itu terus menerus secara turun temurun, atau lebih tepatnya dengan babit kebiasaan yang melekat dalam diri masyarakat, misalkan ketika menghadapi prosesi perkawinan maka harus melakukan tahapan-tahapan dalam adat perkawinan tanpa ada yang terlewatkan. Selain kebiasaan yang turun temurun tersebut salah satu bentuk cara pelestarian budaya di bongak adalah dengan tradisi lisan atau cerita, menceritakan generasi muda oleh generasi tua, lebih tepatnya mereka di ceritakan oleh orang tua mereka.

\section{DAFTAR PUSTAKA}

Al-Toumy, O. M. Falsafah Pendidikan Islam. Jakarta: Bulan Bintang, 1979.

Arifin, S. Studi Agama, Perspektif Sosiologi dan Isu-Isu Kontemporer. Malang: UMM Pres, 2009.

Batubara, H. M. Sosiologi Pendidikan. Jakarta: Ciputat Press, 2004.

Desmita. Psikologi Perkembangan Peserta Didik, Panduan Bagi Orang Tua dan Guru dalam Memahami Psikologi Anak, Sudia SD, SMP dan SMA. Bandung: PT. Rosda Karya, 2012.

Ismail, F. Pijar Islam Pergumulan Kultur dan Struktur. Yogyakarta: LESFI, 2003.

Khadziq. Islam dan Budaya Lokal, Belajar Memahami Realitas Agama dalam Masyarakat. Yogyakarta: Teras Press, 2009.

Kuntowijoyo. Budaya dan Masyarakat Edisi Paripurna. Yogyakarta: Tiara Wacana, 2006. 2008.

Mulkhan, A. M. Nalar Spiritual Pendidikan, Solusi Problem Filosofis Pendidikan Islam. Yogyakarta: PT. Tiara Wacana, 2002.

Mochtar, H. A. Kitab Kuning Dan Tradisi Akademik Pesantren. Jakarta: Pustaka Isfahan, 2010.

Soekanto, S. Sosiologi Sebuah Pengantar. Jakarta: PT. Raja Grafindo Persada, 2007.

Stückelberger, C. Philosophy, Ethics and Local Wisdom in the Moral Construction of the Nation. Terjemahan Siti Syamsiyatun dan Nihayatul Wafiroh. Filsafat, Etika, dan Kearifan Lokal untuk Konstruksi Moral Kebangsaan. Geneva: Globethics.net, 2013.

Tanya, B. L. dkk. Teori Hukum Strategi Lintas Ruang dan Generasi. Surabaya: CV Kita, 2007.

Wiliam F. O. Ideologi-Ideologi Pendidikan. yogyakarta: Pustaka Pelajar, 2008.

Zubaedi, Pendidikan Berbasis Masyarakat Opcit. Yogyakarta: Pustaka Pelajar, Cetakan V, 2009. 